\title{
Effects of different fertilization practices on the quality of stored carrot
}

\author{
AINO-MAIJA EVERS \\ Kemira Oy, Espoo Research Centre, Luoteisrinne 2, \\ SF-02270 Espoo, Finland
}

\begin{abstract}
The effects of different fertilization practices on quality constituents of stored carrots were studied. The field experiments were carried out in southern Finland, and the carrots were stored in refrigerated storage for six months in 1985 and four months in 1986. After storage period the marketable yield and weight loss were measured, carotene content was analyzed and a sensory evaluation for taste and texture was performed in both years. In 1986, also $\mathrm{NO}_{3}-\mathrm{N}, \mathrm{N}, \mathrm{P}, \mathrm{K}, \mathrm{Ca}, \mathrm{Mg}$, ash, glucose, fructose and sucrose were analysed.

In 1985, after storage, NPK fertirrigations without basic fertilization showed a tendency to produce a lower marketable yield than single application and placement fertilization. In 1986, after storage, split application and NPK fertirrigations showed a tendency to produce a lower marketable yield than unirrigated single application. The supraoptimal $\mathrm{N}$ amount showed a tendency to have a higher carotene content than optimal $\mathrm{N}$ amount, and NPK fertirrigations lower $\mathrm{NO}_{3}-\mathrm{N}$ content than irrigated single application. The irrigated placement and broadcast treatments yielded high $\mathrm{K}$ contents. The unfertilized treatments yielded higher marketable yield, lower $\mathrm{NO}_{3}-\mathrm{N}, \mathrm{N}$ and $\mathrm{K}$ contents than fertilized treatments as an average.
\end{abstract}

Index words: carrot, broadcast fert., placement fert., fertirrigation, fertilizer application, quality, storage, organic cultivation

\section{Introduction}

The carrot (Daucus carota L.) is an important vegetable crop both for processing and for the fresh produce market. The storage period in Finland may be as long as six or seven months, from October to March or April. Carrots are harvested while in full metabolic activity. A well-defined stage of biochemical maturity has not been determined (NILSSON 1987), but the optimum harvest date of carrots seems to be reached when the contents of carotene and sucrose are highest and the content of monosaccharides and the respiration intensity are lowest (FrITZ \& HABBEN 1975). The aim of storage is to preserve the same properties as present in the carrot at the time of harvest; yet quantitative and qualitative losses do occur. In literature there is shortage of results of the effects of fertilization 
Table 1. The fertilization treatments and the total amounts of nutrients and irrigation water.

\begin{tabular}{|c|c|c|c|c|c|}
\hline \multirow[t]{2}{*}{ Treatment } & \multirow[t]{2}{*}{$\begin{array}{l}\text { Number and time } \\
\text { of fertilizer } \\
\text { applications }\end{array}$} & \multicolumn{3}{|c|}{$\begin{array}{c}\text { Macronutrient } \\
\text { amounts in } 1986^{3} \\
\mathrm{~kg} / \mathrm{ha}\end{array}$} & \multirow{2}{*}{$\begin{array}{l}\text { Irrigation water } \\
\text { amounts in } \\
1985 \text { and } 1986 \\
\mathrm{~mm}\end{array}$} \\
\hline & & $\mathrm{N}$ & $\mathrm{P}$ & K & \\
\hline \multicolumn{6}{|l|}{ Unfertilized } \\
\hline Unirrigated & 0 & 0 & 0 & 0 & 0 \\
\hline Irrigation & 0 & 0 & 0 & 0 & $3 \times 10$ \\
\hline \multicolumn{6}{|l|}{ NPK placement } \\
\hline Unirrigated & 1 before sowing & 80 & 35 & 133 & 0 \\
\hline Irrigation & 1 before sowing & 80 & 35 & 133 & $3 \times 10$ \\
\hline \multicolumn{6}{|l|}{ NPK broadcast } \\
\hline Unirrigated & 1 before sowing & 80 & 35 & 133 & 0 \\
\hline Irrigation & 1 before sowing & 80 & 35 & 133 & $3 \times 10$ \\
\hline \multicolumn{6}{|l|}{ NPK fertirrigations } \\
\hline No basic & 3 during season & 80 & 29 & 160 & $3 \times 10$ \\
\hline Half the basic ${ }^{\prime}$ & $\begin{array}{l}1 \text { before sowing and } \\
3 \text { during season }\end{array}$ & 80 & 32 & 142 & $3 \times 10$ \\
\hline \multicolumn{6}{|l|}{ PK placement ${ }^{2}$} \\
\hline $3 \mathrm{~N}$-fertirrigations & $\begin{array}{l}1 \text { before sowing and } \\
3 \text { during season }\end{array}$ & 81 & 56 & 133 & $3 \times 10$ \\
\hline $4 \mathrm{~N}$-fertirrigations & $\begin{array}{l}1 \text { before sowing and } \\
4 \text { during season }\end{array}$ & 155 & 56 & 133 & $4 \times 10$ \\
\hline
\end{tabular}

\footnotetext{
Half of the nutrients were given in basic placement fertilization and half in NPK fertirrigations.

${ }^{2}$ Phosphorus and potassium were given in basic placement fertilization and nitrogen in fertirrigations.

3 The nutrient amounts were $30 \%$ higher in 1985 than in 1986 .
}

amounts or practices on the quality of stored carrots.

The purpose of the present investigation is to study whether different fertilization practices during the growing period affect the quality of stored carrot.

\section{Materials and methods}

Carrot cv. Nantes Duke Notabene 370 Sv was cultivated on the Kotkaniemi experimental farm in southern Finland during the growing seasons of 1985 and 1986 (Evers 1988). The field experiments were set up according to the method of completely randomized blocks, with four blocks and ten treatments (Table 1). In NPK placement and NPK broadcast treatments, all nutrients were given in single application. NPK fertirrigations and PK placement with $\mathrm{N}$ fertirrigations treatments were carried out as split application of NPK or $\mathrm{N}$.
The carrots were sown on fine sand soil (15-30\% clay, $12-20 \%$ humus), in the beginning of June. After a four-month growing period the carrots were harvested manually, and $8 \mathrm{~kg}$ (1985) and $15 \mathrm{~kg}$ (1986) samples, packed in wooden boxes, were stored in a refrigerated storage $\left( \pm 0.7^{\circ} \mathrm{C}, 90-95 \% \mathrm{RH}\right)$. In 1986, a bigger amount was stored, because more analyses were done and because the storage ability in 1985 was poor. On 2 April 1986, after six months of storage, and 23 February 1987 , after four months of storage, the samples were weighed to find out the weight loss and thereafter the samples were graded. Because storage loss was so great in 1985, the storage period was in 1986 shorter. The grading was done roughly into two categories only (1) the marketable yield, which included grades I and II and (2) the remnants (broken, wilted and diseased carrots). In both years the carotene content was determined as described in Evers (1989 a). In the used method $\alpha+\beta$ - 
Table 2. The effect of different fertilization practices on the marketable yield and weight loss after storage.

\begin{tabular}{|c|c|c|c|c|c|c|}
\hline \multirow[t]{2}{*}{ Treatment } & \multicolumn{2}{|c|}{1985} & \multicolumn{2}{|c|}{1986} & \multicolumn{2}{|c|}{$\begin{array}{c}\text { Average of years } \\
1985 \text { and } 1986\end{array}$} \\
\hline & $\begin{array}{c}\text { Marketable } \\
\text { yield }{ }^{1} \\
\%\end{array}$ & $\begin{array}{c}\text { Weight } \\
\text { loss }{ }^{2} \\
\%\end{array}$ & $\begin{array}{c}\text { Marketable } \\
\text { yield } \\
\%\end{array}$ & $\begin{array}{c}\text { Weight } \\
\text { loss } \\
\%\end{array}$ & $\begin{array}{c}\text { Marketable } \\
\text { yield } \\
\%\end{array}$ & $\begin{array}{c}\text { Weight } \\
\text { loss } \\
\%\end{array}$ \\
\hline Unfertilized & 21.5 & 26.2 & 69.1 & 14.0 & 45.3 & 20.1 \\
\hline Unfertilized and irrigated & 36.8 & 28.9 & 63.0 & 15.0 & 49.9 & 22.0 \\
\hline Placement fertilized & 39.6 & 23.9 & 63.1 & 17.0 & 51.4 & 20.5 \\
\hline Placement fertilized and irrigated & 41.8 & 25.5 & 60.3 & 15.7 & 51.1 & 20.6 \\
\hline Broadcast fertilized & 36.2 & 26.8 & 63.0 & 16.2 & 49.6 & 21.5 \\
\hline Broadcast fertilized and irrigated & 39.2 & 27.7 & 54.2 & 18.0 & 46.7 & 22.9 \\
\hline NPK fertirrigations, no basic & 22.2 & 31.0 & 58.3 & 16.7 & 40.3 & 23.9 \\
\hline NPK fertirrigations, half the basic & 44.6 & 26.0 & 54.8 & 16.2 & 49.7 & 21.1 \\
\hline PK placement with $3 \mathrm{~N}$ fertirrigations & 46.6 & 25.4 & 55.8 & 15.2 & 51.2 & 20.3 \\
\hline PK placement with $4 \mathrm{~N}$ fertirrigations & 25.5 & 32.1 & 58.4 & 23.0 & 42.0 & 27.6 \\
\hline Mean & 35.4 & 27.4 & 60.0 & 16.7 & 47.7 & 22.1 \\
\hline \multicolumn{7}{|l|}{ Organically cultivated carrots } \\
\hline Location one & & & 86.4 & 13.7 & & \\
\hline Location two & & & 86.0 & 14.0 & & \\
\hline
\end{tabular}

I Indicates how many per cents of the original sample weight was still marketable after storage period.

${ }^{2}$ Indicates how many per cent the $8 \mathrm{~kg}$ sample in 1985 and the $15 \mathrm{~kg}$ sample in 1986 had lost of its weight during storage period.

carotene was determined. The sensory evaluation of taste and texture was done as described in Evers (1989 c). For carrots grown during the growing season of 1986, $\mathrm{NO}_{3}-\mathrm{N}, \mathrm{N}, \mathrm{P}, \mathrm{K}, \mathrm{Ca}, \mathrm{Mg}$, ash, dietary fibre were analysed as described in Evers (1989 b), glucose, fructose and sucrose were analysed as described in Evers (1989 c). Carrot samples grown in 1985 were analysed only from two blocks, and carrot samples grown in 1986 from all four blocks were analysed; but for sensory evaluation carrots from all blocks were pooled, and one sample was evaluated for each treatment. The results were analysed statistically by contrast analysis (STEEL \& TORRIE 1980). The differences between treatments were considered significant at $\mathrm{p} \leq 0.05$, and were considered to show a tendency at $\mathrm{p} \leq 0.1$.

In 1986, samples from two organically cultivated fields were collected for comparison. These carrots were grown from the same seed material, but the geographical position, climate and soil characteristics were different.
Organically cultivated carrots were stored in the same place as the carrots grown in the fertilization experiments. The organically cultivated samples were not compared statistically with those of the fertilization experiment.

\section{Results}

\section{Marketable yield}

In 1985, after a six-month storage period, the marketable yield was only $35 \%$ (mean of all treatments) of the original amount put into storage at harvest. In 1986, after a four-month storage period, the marketable yield was $60 \%$ of the original amount put into storage at harvest (Table 2).

In 1985, no statistical significantly differences in marketable yield after storage were detected between fertilization practices. Some tendencies were observed; placement fertilization, single application and irrigated single application resulted in a higher marketable yield 


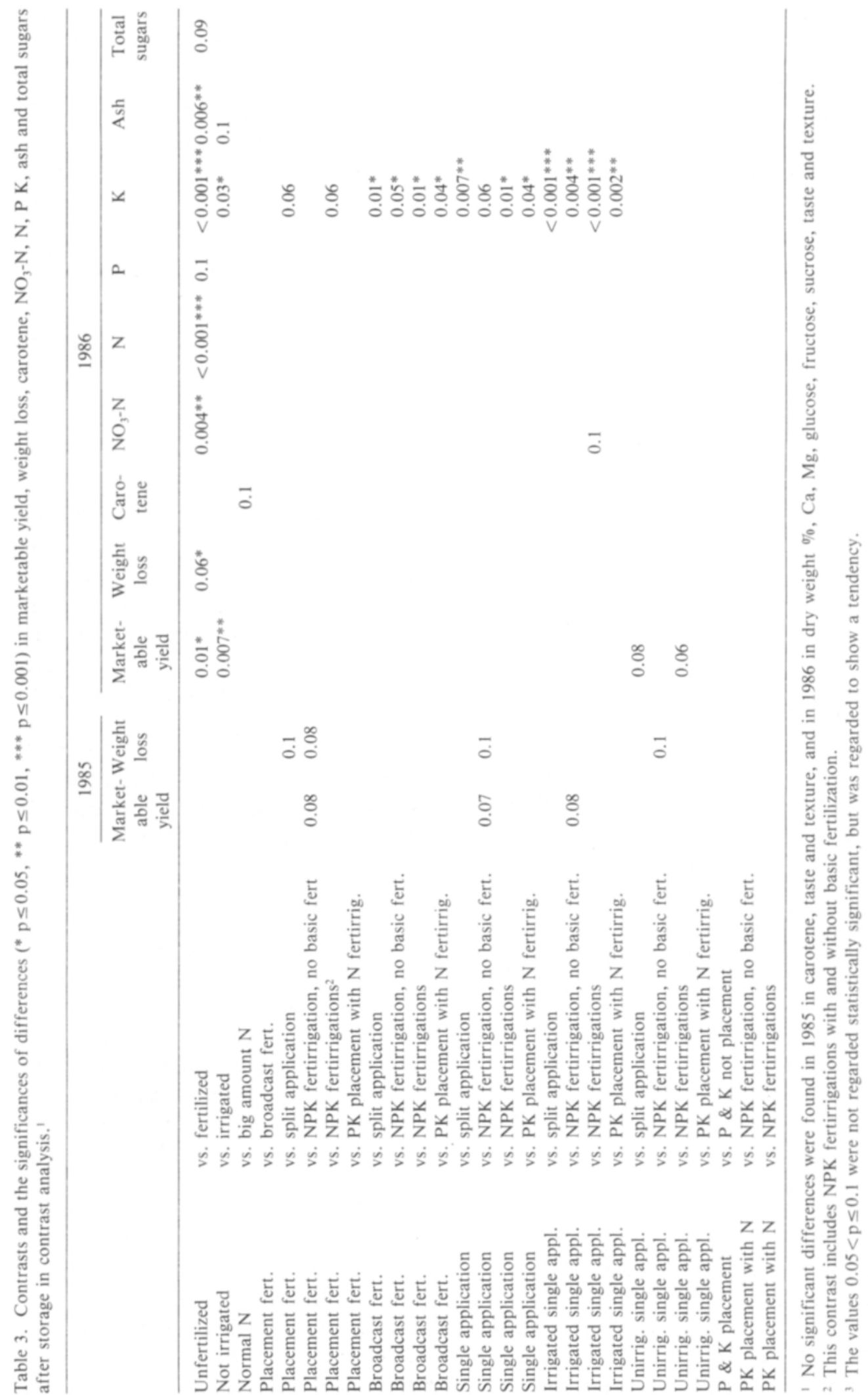


after storage than did NPK-fertirrigations (Table 3).

In 1986, unfertilized and unirrigated treatments resulted in a higher marketable yield after storage than did fertilized treatments or irrigated treatments, respectively (Table 3 ). There was a tendency for unirrigated single application to produce a higher marketable yield after storage than did split application or NPK fertirrigations without or with basic fertilization.

\section{Weight loss}

In all treatments, weight loss averaged $27 \%$ in 1985 and $17 \%$ in 1986 (Table 2). In 1985, no statistically significant differences in weight loss were detected between fertilization practices, but placement fertilization, single application and unirrigated single application had a tendency to have lower weight loss than did NPK fertirrigations (Table 3). In 1986, no significant differences between fertilization practices were observed, but unfertilized treatments had a tendency to have lower weight loss than fertilized treatments (Table 3).

Organically cultivated carrots kept very well in storage. $86 \%$ of the harvested sample was marketable after the storage period. Weight loss was similar to that of carrots grown in the fertilization experiment, but the amount of broken, wilted and infected carrots was much smaller (Table 2).

\section{Dry matter content}

The dry weight increased $1-8 \%$ during the storage period, but there were no significant differences between fertilization practices (Table 4).

\section{Carotene}

At harvest, the carotene content was higher in 1986 than 1985 (Evers 1989 a). After storage the carotene content was lower in 1986 than 1985 (Table 5). In 1985, the carotene content increased in storage in most of the treat- ments, whereas in 1986 it decreased during storage (Table 4).

No statistically significant differences in carotene content after storage between fertilization practices were found. In 1986, there was a tendency for a supraoptimal amount of $\mathrm{N}$ treatment to have a higher carotene content after storage than did treatments with an optimal amount of $\mathrm{N}$ (Table 3). After storage, carrots cultivated organically at location one had a higher carotene content and those cultivated at location two had a carotene content similar to that of carrots grown in the fertilization experiment (Table 5).

\section{Nitrate-nitrogen}

After storage period the unfertilized treatments had significantly lower $\mathrm{NO}_{3}-\mathrm{N}$ content than the fertilized treatments (Table 3). There were no significant differences between fertilization practices, but NPK fertirrigations had a tendency to have lower $\mathrm{NO}_{3}-\mathrm{N}$ content than irrigated single application (Tables 3 and 5).

In organically cultivated carrots the $\mathrm{NO}_{3}-\mathrm{N}$ content was of the same magnitude as the lowest $\mathrm{NO}_{3}-\mathrm{N}$ content of carrots grown in the fertilization experiment (Table 5).

\section{Macronutrients (N, P, K, Ca, Mg)}

The macronutrient contents $(\mathrm{N}, \mathrm{P}, \mathrm{K}, \mathrm{Ca}$ and $\mathrm{Mg}$ ) had increased during the storage period in carrots grown in all the fertilized treatments. The increase was $10-14 \%$ as an average for the treatments as can be calculated from results in Table 4. After storage, carrots in fertilized treatments had significantly higher $\mathrm{N}, \mathrm{P}$ and $\mathrm{K}$ contents than did unfertilized treatments (Table 3). This was the only statistically significant difference observed in $\mathrm{N}$ and $\mathrm{P}$ contents. Many significant differences in $\mathrm{K}$ content were detected in many contrasts (Table 3), but all these are based on high $\mathrm{K}$ contents after storage in irrigated single applications eg. irrigated broadcast and irrigated placement fertilization (Table 5). 


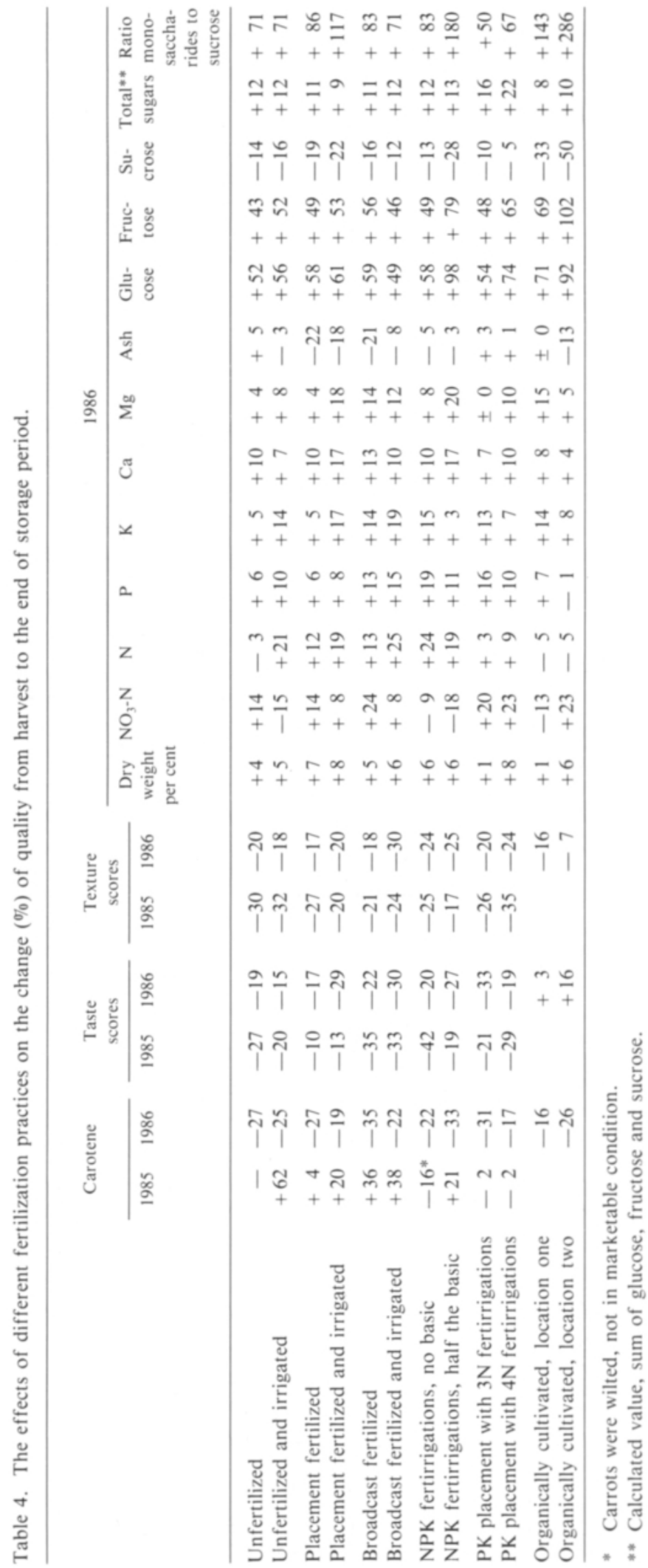




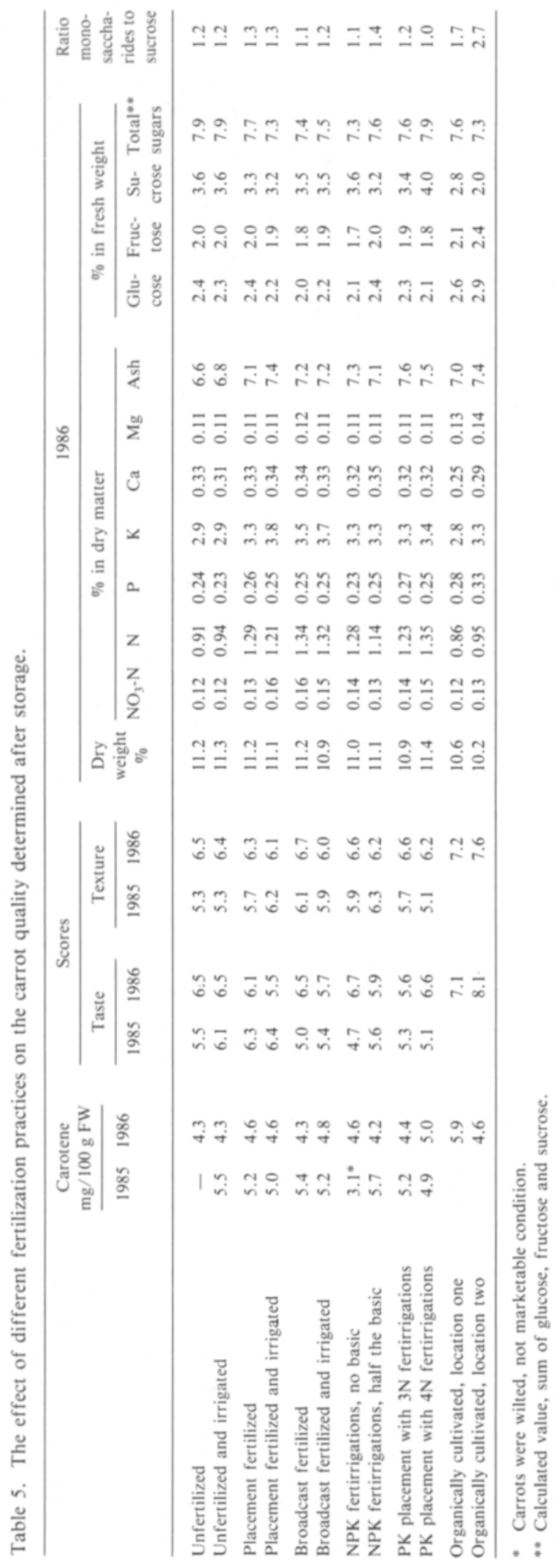


In organically cultivated carrots, the $\mathrm{N}$ and $\mathrm{Ca}$ contents were lower, the $\mathrm{P}$ and $\mathrm{Mg}$ contents were higher, and the $\mathrm{K}$ contents were similar to that of carrots grown in the fertilization experiments (Table 5).

\section{Ash}

During storage the ash content decreased in carrots cultivated in most of the treatments, but in carrots grown in unfertilized and in PK placement with $\mathrm{N}$ fertirrigations there was a slight increase (Table 4). No statistically significant differences between fertilization practices could be observed, but after storage the ash content was higher in carrots grown in fertilized treatments as compared to unfertilized treatments (Table 3). In irrigated treatments the ash content showed a tendency to be higher after storage as compared to unirrigated treatments (Table 3). After storage the ash content of the organically cultivated carrots was similar to that of carrots grown in fertilized treatments in the fertilization experiment (Table 5).

\section{Sugars}

The glucose and fructose contents increased and the sucrose content decreased during the storage period (Tabie 4). The calculated total sugar content (glucose + fructose + sucrose) increased and the ratio of monosaccharides to sucrose increased during the storage period (Table 4).

No significant differences between treatments could be found as to the glucose, fructose, sucrose and total sugar contents of carrots. The total sugar content in carrots grown in unfertilized treatments had a tendency to be higher than in carrots grown in fertilized treatments (Table 3).

In organically cultivated carrots, the glucose content was higher than that of carrots grown in the fertilization experiment (Table 5). The fructose content was high at location two. The sucrose content was lower than in the fertilization experiment. Thus the ratio of monosac- charides to disaccharides was higher in organically cultivated carrots. The total sugar content was similar between the carrots grown in the fertilization experiment and the organically cultivated carrots (Table 5).

\section{Taste and texture}

The fertilization practices had no effect on taste or texture evaluated after storage, but the taste and texture scores were lower after the storage period than after harvest (Table 4). The organically cultivated carrots were an exception; their taste was poor at harvest (EVERS $1989 \mathrm{c}$ ), but after the storage period they received the best taste scores (Table 5).

\section{Discussion}

\section{Marketable yield}

In the present study the marketable yield of stored carrots was especially low in 1985, as the mean of treatments being $35 \%$. In Finland the average amount of marketable yield after 5-6 months storage is about $70 \%$ (MuKULA 1957). In 1986, in the present study, the marketable yield after 4 months storage averaged $60 \%$ and was thus slightly lower than the average. The main reason for the poor storage ability was heavy infection by Mycocentrospora acerina (R. Hartig) Deighton, know also by synonym Centrospora acerina, a soilborne disease (FJELDDALEN \& RAMSFJELL 1969). In 1985, the storage period was longer than in 1986, thus the infection destroyed more carrots. Also weather conditions may have contributed to the particularly poor result in 1985. MuKULA (1957) demonstrates that varying climatic conditions in the growing districts affect the ability to keep, so that carrots grown in northern Finland incur greater losses in storage than carrots grown in central Finland, and in turn, carrots grown in the latter region have greater losses than those grown in southern Finland. In the present study, the mean day temperature and the number of sunshine hours in June and July 
in 1985 were lower than in 1986, and lower than the long-term averages (Evers 1988).

The average marketable yield after six months of storage in the study of NiLsson (1979) is $66 \%$, and the type (organic vs. inorganic) or amount of fertilizer applied have no effect on it during refrigerated storage. In the present study, too, no statistically significant differences in marketable yield after storage could be found between fertilization practices. However, split application or NPK fertirrigations showed a tendency to lower the marketable yield after storage. In 1986, the reason for this may be the water given with split or NPK fertirrigations treatments, because in 1986 the irrigation decreased significantly the marketable yield, and the split application and the NPK fertirrigation treatments had negative effects especially as compared to unirrigated single applications. In 1985, the NPK fertirrigations without basic fertilization decreased the marketable yield after storage as compared to placement fertilization, single application and irrigated single application, and thus water cannot be the reason for impaired storage ability in 1985. It would be interesting to study this subject further to confirm this observation and to find out the possible mechanism of action.

DRAGLAND (1978) reports that the time of irrigation does not affect the storage ability, but that an early drought period results in high root yield and good storage ability. $\mathrm{He}$ also reports that the nitrogen amount does not cause any statistically significant differences in storage ability, but an increasing amount of nitrogen shows a tendency to improve storage ability. In the present study, no such improvement could be detected. The treatment PK placement with $4 \mathrm{~N}$ fertirrigations did get a supraoptimal $\mathrm{N}$ amount, but it showed rather worse than better keeping ability than did treatment with an optimal $\mathrm{N}$ amount (Table 2).

\section{Weight loss}

The weight loss was not affected by the fertilization practices in the present study. Also in Nilsson's (1979) study the type of fertilizer (organic vs. inorganic) or amount of fertilizer applied had no effect on weight loss. In his study the mean weight loss (including trimming loss) is $22 \%$. FrITz et al. (1979) reports a very close relation of storage losses and weather conditions of the last two weeks before harvesting. The sum of the rainfall as well as the average relative humidity are important determining variables, and the researchers hypothesizes that weight losses of vegetables are the lower the more turgid the plants were at harvest.

\section{Dry matter}

In the present study, the dry matter content increased slightly during storage, which indicates that the weight loss through water transpiration has been greater than the weight loss through dry matter consumption in respiration. The different fertilization practices did not effect the dry weight during storage. Nor do the type or the amount of fertilizer affect the dry matter content of stored carrots (NILSSON 1979).

\section{Carotene}

The supraoptimal $\mathrm{N}$ amount did not affect the carotene content in carrots at harvest (Evers 1989 a) contrary to Freeman \& HarRIS (1951) and HABBEN (1972), who have found that increasing the amounts of nitrogen also increases the carotene content. However, after storage in the present study in 1986, the supraoptimal amount of $\mathrm{N}$ in treatment PK placement with $4 \mathrm{~N}$ fertirrigations had a tendency to have higher carotene content as compared to other treatments, where the $\mathrm{N}$ amount applied was though to be optimal on the basis of the yield. The decrease of carotene in the treatment $\mathrm{PK}$ placement with $4 \mathrm{~N}$ fertirrigations was the smallest of all treatments (Table 4).

Carotene changed differently in the two years; for it increased in many treatments in 1985 and decreased in 1986 during storage. 
Also the literature contains reports of contradictory results. BARNES (1936) has found that the carotene content decreases during storage; FrITZ et al. (1978) have found that the carotene content increases during storage, and they explain the increase as a concentrating effect occurring because the amount of dry matter decreases by respiration during storage. NiLSSON (1979) does not find any significant differences in carotene content during storage in carrots grown with organic vs. inorganic fertilizers and with two fertilizer levels applied.

The carotene is determined from fresh carrots and the results are expressed in $\mathrm{mg} / 100$ $\mathrm{g}$ fresh weight. Thus the increase in carotene content could be explained not only by the concentrating effect mentioned by FrITZ et al. (1978), but also by loss of water through transpiration. In addition, LEE (1986) reports that biosynthesis of carotenes occurs in carrots during storage, and in his study the content of $\alpha$ - and $\beta$-carotene increases slowly for up to $100-125$ days in storage and then decreases. The decrease in carotene content observed in the present study in 1986 may be the result of further biosynthesis or decomposition of the compound. Because carrots are an important vegetable consumed in Finland also in winter, it would be very important to study further the reasons for carotene changes in storage and the factors influencing it.

\section{$\mathrm{NO}_{3}-\mathrm{N}$ and macronutrients}

The $\mathrm{NO}_{3}-\mathrm{N}$ and macronutrient contents increased in most of the treatments and this trend is probably due to the water loss and the loss of dry matter respiration. As to $\mathrm{NO}_{3}-\mathrm{N}$, the treatments NPK fertirrigations without or with basic fertilization made an exception. Their $\mathrm{NO}_{3}-\mathrm{N}$ contents had decreased during storage. These treatments had the highest $\mathrm{NO}_{3}-\mathrm{N}$ contents at harvest (EvERs 1989 b) and probably, for some reason, the change from $\mathrm{NO}_{3}-\mathrm{N}$ to amino-nitrogen was delayed in these treatments. They showed even a tendency to have lower $\mathrm{NO}_{3}-\mathrm{N}$ content after storage than irrigated single application.
Ash

The decrease in ash content in most of the treatments was unexpected, while all the determined minerals increased during stor?ge. This result should be verified in future studies.

\section{Sugars}

Glucose and fructose contents increased during storage in all treatments. This is in agreement with literature (BARNES 1936, SAlminen et al. 1970, Nilsson 1979). Sucrose content decreased during storage in all treatments. Also in the study of NiLsson (1979) the sucrose content decreased during storage. The magnitude of changes in glucose, fructose and sucrose were similar in the present study and in the study of NiLSSON (1979). In the studies of BARnes (1936) and SALMinen et al. (1970) the sucrose content increased during the first months of storage and then decreased approximately to the level determined at harvest. In the present study, the ratio between monosaccharides to sucrose, and the total sugar content increased during storage. In the present study and in the study of NILSSON (1979) the increase of monosaccharides was greater than the simultaneous decrease of sucrose, and NiLSSON (1979) hypothesizes that polysaccharides have been hydrolysed during storage. $\mathrm{He}$ also reports that the type or amount of fertilizer do not affect carrot sugar contents after storage. In the present study, the fertilization practices had no effect on the changes of glucose, fructose and sucrose during storage. The total sugar content had a tendency to be higher in unfertilized treatments than in fertilized treatments as an average. The situation was similar already at harvest (Evers 1989 c). In unfertilized treatments the lack of nutrients probably have restricted the phytomass production and thus more photosynthates were left to be translocated into the storage cells.

\section{Taste and texture}

The indicative results of sensory evaluation at harvest indicates that NPK fertirrigations 
have a positive effect and the placement of NPK fertilizer has a negative effect on taste and texture (Evers 1989 c). After storage these trends could not be shown anymore, and fertilizati on had no effect on taste and texture. Carrot aroma is very complex and many compounds influence it (SIMON 1985). Possibly, during storage, the amounts or proportions of one or several of those compounds have changed, because the metabolic activity can be minimized but not stopped by lowering the temperature in refrigerated storage.

\section{Organically cultivated carrots}

Organically cultivated carrots were not in- fected by the soilborne Mycocentrospora acerina (R. Hartig) Deighton, and thus their marketable yield after storage was considerably higher than that in the fertilization experiment. After storage, the contents of $\mathrm{P}, \mathrm{Mg}$, glucose, fructose, and carotene at location one as well as the taste and texture scores were higher in organically cultivated carrots than in carrots grown in fertilization experiment. On the other hand, the dry matter, $\mathrm{N}$ and $\mathrm{K}$ contents at location one as well as $\mathrm{Ca}$ and sucrose were lower in organically cultivated carrots than in carrots fertilized conventionally. The $\mathrm{NO}_{3}-\mathrm{N}$ contents in organically cultivated carrots were similar to the lowest values in the fertilization experiment.

\section{References}

Barnes, W.C. 1936. Effects of some environmental factors on growth and color of carrots. Cornell Univ. Agric. Exp. Sta. Mem. 196: 1-36.

Dragland, S. 1978. Nitrogen- og vassbehov hos gulrot. Forskn. Förs. Landbr. 29: 139-159.

EvERS, A-M. 1988. Effects of different fertilization practices on the growth, yield and dry matter content of carrot. J. Agric. Sci. Finl. 60: 135-152.

- 1989 a. Effects of different fertilization practices on the carotene content of carrot. J. Agric. Sci. Finl. 61: $7-14$.

- 1989 b. Effects of different fertilization practices on the $\mathrm{NO}_{3}-\mathrm{N}, \mathrm{N}, \mathrm{P}, \mathrm{K}, \mathrm{Ca}, \mathrm{Mg}$, ash and dietary fibre contents of carrot. J. Agric. Sci. Finl. In press.

- 1989 c. Effects of different fertilization practices on the glucose, fructose, sucrose, taste and texture of carrot. J. Agric. Sci. Finl. In press.

Fjelddalen, J. \& Ramsfjell, T. 1969. Sykdommer og skadedyr pá jordbruksvekster. 259 p. 2nd Ed. Oslo.

Freeman, J.A. \& Harris, G.H. 1951. The effect of nitrogen, phosphorus, potassium and chlorine on the carotene content of the carrot. Sci. Agric. 31: 207-211.

FrITZ, D. \& HabBen, J. 1975. Determination of ripeness of carrots (Daucus carota L.). Acta Hort. 52: $231-238$.

—, KÃppel, R. \& Weichmann, J. 1978. Einfluß des Anbaues auf Lagereignung und Lagerverhalten von Obst und Gemüse. Ernähr. - Umschau. 25: 78-84.

—, Weichmann, J. \& KĂppel, R. 1979. Einfluß des Erntezeitpunktes auf die Lagerfähigkeit von Möhren.
Gartenbauwiss. 44: 4-9.

HabBen, J. 1972. Einfluss von Düngung und Standort auf die Bildung wertgebender Inhaltsstoffe in Möhren (Daucus carota L.). Diss. Techn. Univ. München.

LEE, C.Y. 1986. Changes in carotenoid content of carrots during growth and post-harvest storage. Food Chem. 20: 285-293.

Mukula, J. 1957. On the decay of stored carrots in Finland. Acta Agric. Scand. Suppl. 2: 1-132.

NiLsson, T. 1979. Avkastning, lagringsförmåga, kvalitet och kemisk sammansăttning hos morot, vitkál och purjo vid konventionell och organisk gödsling. Inst. Trädg. Vet. Rapp. 7: 3-52.

- 1987. Growth and chemical composition of carrots as influenced by the time of sowing and harvest. J. Agric. Sci. Camb. 108: 459-468.

Salminen, K. Karinpäa, A., Koivistoinen, P. \& MukuLA, J. 1970. Postharvest chemistry of carrots as such and modified by the preharvest use of herbicides chlorpropham (CIPC) and linuron. Acta Agric. Scand. 20: 49-57.

Sımon, P.W., 1985. Carrot flavor: effects of genotype, growing conditions, storage and processing. In: "Evaluation of quality of fruits and vegetables". (Ed. H.E. Pattee), p. 315-328. Westport, Connecticut.

Steel, R.G.D. \& Torrie, J.H. 1980. Principles and procedures of statistics. A biometrical approach. 633 p. 2nd Ed. Tokyo.

Ms received March 16, 89 


\section{SELOSTUS}

\section{Lannoitusmenetelmien vaikutus varastoidun porkkanan laatuun}

\author{
Aino-Maija Evers \\ Kemira Oy, Espoon tutkimuskeskus \\ Luoteisrinne 2, 02270 Espoo
}

Eri lannoitusmenetelmien vaikutusta porkkanan 'Nantes Duke Notabene 370 Sv' varastoinnin jälkeiseen laatuun tutkittiin vuosina 1985 ja 1986 . Kenttäkokeissa Kotkaniemen koetilalla Vihdissă oli vertailtavina lannoitusmenetelmină sijoitus- ja pintalannoitus (ilman kastelua ja kastelun kera), NPK-kastelulannoitus ja NPK-kastelulannoitus, jossa puolet ravinteista annettiin sijoittaen keväăllă, sekä koejäsenet, joissa $\mathrm{P}$ ja $\mathrm{K}$ annettiin sijoittaen keväällă ja N (kaksi tasoa) kastelulannoituksena kasvukaudella. Kokeessa verrattiin myös ravinteiden kertalevitystă jaksotettuun ravinteiden antoon. Neljän kuukauden kasvuajan jälkeen käsin tehdyn sadonkorjuun yhteydessă 8 kg:n (1985) ja 15 kg:n (1986) näytteet vietiin koneellisesti jäăhdytettyyn varastoon $\left( \pm 0.7^{\circ} \mathrm{C}, 90-95 \%\right.$ $\mathrm{RH}$ ). Varastointiaika oli $6 \mathrm{kk}$ vuonna 1985 ja 4 kk vuonna 1986. Varastoinnin jălkeen năytteistă punnittiin painohäviö ja kauppakelpoinen sato (I ja II luokat yhteensä), määritettiin karoteenipitoisuus ja aistinvaraisella arvioinnilla arvosteltiin maku ja rakenne. Vuonna 1986 määritettiin myös $\mathrm{NO}_{3}-\mathrm{N}, \mathrm{N}, \mathrm{P}, \mathrm{K}, \mathrm{Ca}, \mathrm{Mg}$, tuhka, glukoosi, fruktoosi ja sakkaroosi. Tulokset analysoitiin kontrastianalyysillä.
Vuonna 1985 NPK-kastelulannoitusta saaneiden porkkanoiden varastoinnin jälkeinen kauppakelpoinen sato oli suuntaa-antavasti $(\mathrm{p} \leq 0.1)$ alhaisempi kuin koejäsenissä, jotka saivat ravinteita vain yhden kerran kasvukauden alussa, ja alhaisempi kuin sijoituslannoituksen saaneissa koejäsenissä. Vuonna 1986 varastoinnin jälkeinen kaupakelpoinen sato oli alhaisempi koejäsenissä, jotka saivat ravinteet jaksottain, ja koejäsenissä, jotka saivat NPKkastelulannoitusta, kuin koejäsenessä, jossa ravinteet annettiin kerran kevăăllă eikă kasvukaudella kasteltu. Ylisuuren typpimäärän saaneen koejăsenen karoteenipitoisuus oli varastoinnin jälkeen korkeampi kuin sadontuottokyvyn perusteella optimaalisen typpimäärän saaneilla koejäsenillă, ja NPK-kastelulannoitusta saaneiden koejäsenten $\mathrm{NO}_{3}$-N-pitoisuus oli alhaisempi kuin koejäsenten, jotka saivat kastelua ja kaikki ravinteet kerralla kevăällă. Sijoitus- ja pintalannoituksen kastelun kera saaneiden koejäsenten $\mathrm{K}$-pitoisuudet olivat korkeat varastoinnin jälkeen. Lannoittamattomien koejäsenten kauppakelpoinen sato oli korkeampi ja $\mathrm{NO}_{3}-\mathrm{N}-, \mathrm{N}$ - ja K-pitoisuudet matalammat kuin lannoitettujen koejäsenten vastaavat pitoisuudet. 